\title{
Lessons from COVID-19
}

Regardless of the impact and even commotion that the so-called COVID-19 has been producing, for justifiable reasons, along with public opinion, the government, and most particularly, among managers and health professionals around the world, it is interesting and curious to point out that the well-known common flu (influenza) is, in fact, according to historians and analysts of the health/disease process, the most common infection and the greatest cause of death worldwide. 1,2 And this is not something recent, reliable statistical information and records are available until today. In the case of the COVID-19 pandemic, every 24 hours, the balance of new cases and deaths from the new coronavirus has been released, practically in real time, in almost every country in the world, connected by the World Health Organization (WHO).

In reality, the climate of public calamity in which all nations have come to live with, even if their territorial space had no proof of initial cases of the coronavirus, is becoming possible the emergence of a new universal consciousness about health problems of all humanity, independently even of eventual or historical geopolitical incompatibilities. It is evident that the precursory character of this perspective cannot be assumed, even now, as a definitive guarantee that the various goals of the United Nations in the health sector, foreseen and agreed for the next 20,30 or 40 years, starting with the milestone of the new millennium, will be able to assume a safe transit. However, the simple fact of having, at the end of each night, a quickbalance of how and when COVID19 has been circulating around the world, and the progress of related measures, is of great importance for the awareness of the generalpopulation, and for the health professionals and managers'decision-making in the application of general and specific measures for its control.

It seems unquestionable that the experience of the new coronavirus pandemic, in factis being, a "health tragedy", by reopening paths for a conceptual redefinition about nature, conditioning and correlated factors, the limitations, and on the other hand, promising perspectives for health policies and programs in each and every country or nations. It is already accepted that this is not just a new pandemic, characterized in the concepts and indications of epidemiology and classical public health. Thus, the theoretical support of a new concept is required: the syndemic, which, without excluding the conventional indicators of the health/disease process, rescues the environment in the dynamism of its economic and social factors, incorporating values of spirituality itself. These are, inclusive, the referential points of a new and promising doctrine of human development, already anticipated more than half a century ago by a Brazilian author (Josué de Castro) and, by now, accepted and consolidated by the United Nations.

Therefore, anchored in historical background and conceptual principles, which today justify the interest of new approaches to the problem of COVID-19, now spread across all continents, we clarify here the situation of 50 countries that, in order of prevalence, represent a situation of more than $60 \%$ of the entire human population. 3,4 The progress of the pandemic was developed through basic indicators (number of confirmed cases and lethality), in order to compare the information published daily by WHO.

These "lessons"... are not, formally, a study with a logically linked beginning, middle, and end, but a set of ideas and impressions that are imposed as points of initial reflections on the here and now of various facts that 
are occurring in the chronicle of daily events and that can be fixed as possible starting points for future developments. It is an impressionistic agenda of facts and lessons.

In the brief and turbulent history of the pandemic it can be confirmed that the mutations of the virus are more frequent than the changes in man's own habits of consumption, values and life practices. Science and its weapon (technology) can eventually maintain itself, as a principle or as a use, in the short space of a generation (conventionally 25 years) in some countries in the world. Now, with the coronavirus and its transit in the paths of humanity, without coordinating latitude and longitude, a new and surprising anomaly is configured: the typologies of strains that make, for example, the United Kingdom to impose travel restrictions to Brazilians to its territory, given the evidence that about 40 cases of the patients are already carriers of the co-variants of the virus. How far can these developments go? Even the risk of these variants arebecoming "more dominant". And an essential Brazilian byproduct of the pandemic, Malta et al.,5 published an interesting study on Brazilian adults changing their lifestyles (more than 45,000 cases over 18 years of age), regarding tobacco consumption, alcoholic beverages, diet, and physical activity, during the period of social restriction, due to the pandemic, it was concluded that lifestyles and health risk behaviors worsened.5 It would be an aggravating evidence of the syndrome that has increased the most in Brazil since 1975 - the overweight/obesity dyad in the adult population, reached one of the highest levels in the world.

Of course, other consequences can be positive. It has already been observed that air pollution, through the moderation of automobile traffic, would have dropped by $8 \%$. On the other hand, with family seclusion recommended by the quarantine, assaults on women and children would have increased by the same proportion: $8 \%$. Obviously, things cannot be analyzed in the simple relationship of changes in quantitative signs of profit and loss, but the simple registration of fields of variation or such specific parameters becomes indicative of perspectives that can be opened up and reused. And a challenge that cannot be omitted: how to resume an economic development path that has been severely affected by the pandemic? In the case of Brazil, the very recent inclusion of truck drivers in the priority groups for vaccination can be praised as a happy intervention of the health sector to clarify economic proposals, taking into account the importance of road transport in the circulation of wealth.

In fact, everything indicates that after this pandemic, the world will no longer be the same. There was a good pause for meditation, and it is logical that the domestic "assembly" that mobilized between $40 \%$ and $60 \%$ of the world's active labor force was enough to debate a large part of the human problems. At least there has never been so much time available for a meeting with so much room for such an open debate in the family sphere. In the field of concrete balances, the simple report that within nine months, emblematically the duration of a pregnancy, since the registration of the first 40 cases of the epidemic in Wuhan, until last November, 6 or 7 vaccines have been discovered in different countries. Never before in the entire history of epidemics and preventive vaccinations has there been a similar performance. It is also true that, besides humanitarian altruism, it seems (and very much so!) to be the overwhelming force of the market, making the vaccine an attractive source of profits in the demand pole.

In fact, we are at the mercy of the uncontrolled winds (and sales), expecting history to strengthen things out by putting a semifinal point on this process that has killed more than the two world wars combined.

\section{References}

1. Felinto GM, Escosteguy CC, Medronho RA. Fatores associados ao óbito dos casos graves de influenza A (H1N1) pdm09. Cad Saúde Coletiva. 2019; 27 (1): 11-9.

2. Forleo Neto, Halker E, Santos VJ, Paiva TM, Toniolo Neto J. Influenza. Rev Soc Bras Med Trop. 2003; 36 (2): $267-74$.

3. WHO (World Health Organization). WHO Coronavirus Disease (COVID-19) Dashboard. [acesso jan 2021] Disponível em: https://covid19.who.int/

4. World o meter. Reported cases and deaths by country or territory. [acesso jan 2021] Disponível em: https://www.worldometers.info/coronavirus/\#countries

5. Malta DC, Szwarcwald CL, Barros MBA, Gomes CS, Souza Jr PRB, Romero DE, Lima MG, Damacena GN, Pina MF, Freitas MIF, Werneck AO, Silva DRP, Azevedo LO, Gracie R. A pandemia da COVID-19 e as mudanças no estilo de vida dos brasileiros adultos: um estudo transversal, 2020. Epidemiol Serv Saúde. 2020; 29 (4): e2020407. 
Malaquias Batista Filho 1

(iD) https://orcid.org/0000-0002-1490-0590

Eduarda Ângela Pessoa Cesse 2

iD https://orcid.org/0000-0001-5745-3981

Déborah Lemos Freitas 3

iD https://orcid.org/0000-0002-6068-8623

Leonardo Vidal Batista 4

(iD) https://orcid.org/0000-0002-1069-3002

1,3 Instituto de Medicina Integral Prof. Fernando Figueira. Rua dos Coelhos, 300. Boa Vista. Recife, PE, Brasil. CEP: 50.070-902.

2 Centro de Pesquisas Aggeu Magalhães. Fundação Oswaldo Cruz. Recife, PE, Brasil

4 Centro de Informática. Universidade Federal da Paraíba. João Pessoa, PB, Brasil. 